\title{
Costs and recovery rates in the Dutch liquidation-based bankruptcy system
}

\author{
Oscar Couwenberg $\cdot$ Abe de Jong
}

Published online: 10 July 2008

(C) The Author(s) 2008

\begin{abstract}
We present evidence on the efficiency of the resolution of financial distress in bankruptcy in The Netherlands. Direct costs average 16\%, firm recovery $37 \%$ and bank debt recovery $80 \%$. The direct costs are lower in larger firms and in firms with more bank debt. Costs increase with the time it takes to sell assets. Firm recovery is influenced by asset structure, capital structure and to a lesser extent Dutch legal variables. However, the opportunity to continue operations in bankruptcy is chosen by about half the firms and this has a positive effect on recoveries.
\end{abstract}

Keywords Bankruptcy $\cdot$ Liquidation $\cdot$ Direct costs $\cdot$ Recovery rates

JEL Classifications $\quad \mathrm{G} 33 \cdot \mathrm{K} 22$

\section{Introduction}

In the law and finance literature, the rights of investors play a key role in firm's financing and governance structures, but also in the financial development of countries. Insolvency laws are to be considered an integral part of the complex bundle of property rights creditors have. Claessens and Klapper (2005) argue that a good insolvency regime prevents managers from taking imprudent loans and borrowers from lending with high default probability, while still stimulating

O. Couwenberg ( $($ )

Faculty of Law, Department of Law and Economics, University of Groningen, Oude Kijk in 't Jatstraat 26, P.O. Box 716, 9700 AS Groningen, The Netherlands e-mail: o.couwenberg@rug.nl

A. de Jong

Department of Finance, Rotterdam School of Management Erasmus University, Rotterdam, The Netherlands e-mail: ajong@ $\mathrm{rsm} . n l$ 
entrepreneurship in the economy. Moreover, it is important the regime enables a time and cost efficient resolution of the financial distress in case of insolvency.

This paper provides empirical evidence on the efficiency of the resolution of financial distress of Dutch bankrupt firms. We document and explain direct costs and recovery rates because these are the key variables that determine the efficiency of bankruptcy laws, rules and practices. We investigate a unique data set of 137 Dutch bankruptcies, based on the files of trustees and court offices. This data includes the characteristics of the firms, the details of the bankruptcy process and the outcomes.

The contribution of our analysis is twofold. First we add to the ongoing discussion about bankruptcy systems and their efficiency. We compare our findings for the Dutch liquidation-based system to other studies in similar and different systems, such as the US reorganization-based system. A recent analysis by Djankov et al. (2006) shows that The Netherlands is particularly interesting, because in a sample of 88 countries, Dutch procedures and practices lead to the highest efficiency score in liquidation-based resolutions. Because Djankov et al. (2006) apply a stylized setting based on a single case, it is interesting to consider a large sample of actual cases in the Dutch system.

Our second contribution is that we focus both on firm characteristics and on the details of the Dutch legal procedures. Within the boundaries of the legal setting, the management, creditors and trustees influence the results of the resolution of distress by their decisions to engage in or abstain from using certain legal procedures. For example, creditors can dispute against the trustees' ruling and the trustee has the option to continue operations during the procedure. In existing studies this discretion is largely ignored. Thus, while a comparison with other countries allows us to investigate whether the Dutch legal environment has an effect on the efficiency of the bankruptcy process, we can also measure the influence of specific procedures on efficiency within the Dutch setting.

We find that direct costs are on average $16 \%$ of realized assets. The costs are lower in larger firms and in firms with more bank debt, while costs increase with the time it takes to sell assets and the number of disputes the trustee has to deal with. The firm recovery rate is on average $37 \%$. The firm recovery rate in our study is influenced by the asset structure and the capital structure. Moreover, continuation in bankruptcy improves the recovery rates, whereas liquidation has a negative effect. Overall, we find strong effects on costs and recovery of firm characteristics, i.e. size, asset structure and capital structure. Additionally, we find that some characteristics of the legal procedures turn out to influence costs and recovery. Particularly, the number of disputes increases the costs and the opportunity to continue operations in bankruptcy — chosen by about half the firms - has a positive effect on firm recovery rates. Despite the relevance of these legal procedures, our overall conclusion is that bankruptcy costs and recovery rates are mainly driven by firm characteristics. Our results partly explain why Djankov et al. (2006) in their study find that The Netherlands has a relatively efficient bankruptcy system. The firm characteristics proxy for asset value, which in turn drives recovery rates. Legal procedures may consume cash or destroy asset value, but may also enhance recovery. In this study, we find little negative effects and some positive ones. Thus, what matters in the 
Dutch regime is not so much the rules, but the economic characteristics of firms filing for bankruptcy that explain costs and recovery.

The structure of this paper is as follows. Section 2 gives a brief description of the existing theoretical and empirical work on costs and recovery rates and of the Dutch bankruptcy system. Section 3 describes our data set. Section 4 provides summary statistics and the regression analyses for direct costs and recovery rates of Dutch bankrupt firms. Section 5 concludes.

\section{International bankruptcy codes}

This section reviews the literature on international differences in bankruptcy codes, including the theoretical motivation for bankruptcy research (Sect. 2.1) and recent empirical evidence in the US and European countries (Sect. 2.2). We also briefly describe the Dutch bankruptcy system (Sect. 2.3).

\subsection{Bankruptcy theory}

Our analysis of costs and recovery rates in bankruptcy procedures in the Dutch setting is an empirical test, and the results of this test can be compared with other empirical studies in different settings. The overall purpose of these tests will be described in this section as we use these outcomes to judge the efficiency of bankruptcy codes and practices within a theoretical skeleton for our work.

The efficiency of a bankruptcy system can be evaluated for the three stages of the bankruptcy process (Franks et al. 1996). The first stage is ex ante, i.e. prior to the financial distress, when investments are contemplated, debt contracts are initiated (Holmstrom and Myerson 1983) and capital structure decisions are made (Gertner and Scharfstein 1991; Haugen and Senbet 1978). An efficient bankruptcy system prevents that entrepreneurs without viable prospects, i.e. positive NPV investment options, take out loans to finance these, or decide upon an inefficient level of leverage (White 1996). As with other areas of law, e.g. criminal law or liability law, bankruptcy law thus aims to provide incentives for entrepreneurs to actually limit the usage of the legal procedures for bankruptcy (see e.g. Calabresi 1970).

The second stage is the interim stage, during the distress and the bankruptcy procedure (Franks et al. 1996). Although an efficient system leads to quick solutions to the problems, this is often, especially for the larger bankruptcies, not easy to achieve (Bris et al. 2006; Weiss 1990). As the problems can be financially and economically oriented, the decision-making processes will be driven by rules in the bankruptcy system and will be tainted by conflicts of interests of participants (Baird 1996; Brown 1989; Maksimovic and Phillips 1998). These conflicts depend on the contractual rights of participants and associated negotiation power. Depending on the rules in a bankruptcy law, these conflicts have to be solved while simultaneously finding a solution to the financial and/or economic distress.

The third and final stage is ex post, when all distributions have been made. Ex post efficiency is achieved if decision making has used all available information, 
such that all creditors and other parties receive the highest payouts possible and in accordance with contractual rights. In other words, inefficiencies arise when bankruptcy process costs are high, when recovery rates are low, when distributions are not driven by priority rules, and when substantial renegotiation takes place (Franks et al. 1996).

The three stages together are decisive whether or not a bankruptcy law can be characterized as being efficient. However, the first phase is empirically difficult to research. The second and third phase can empirically be studied by actual costs, recovery rates, deviations from priority rules and throughput times. These empirical proxies have already been analyzed for a small set of bankrutpcy systems, notably in the United States. This empirical research will be discussed below. The contribution of this paper lies in analyzing these efficiency proxies for a bankruptcy system that is geared towards liquidation. There is a notable lack of empirical research on this kind of system as to inform the discussion what its benefits are and its inefficiencies.

\subsection{Bankruptcies around the world}

In the empirical literature on the effects of bankruptcy two types of studies have emerged. In the first set, country-level bankruptcy law and judicial efficiency variables are related to other country characteristics in order to measure the macroeconomic implications of bankruptcy systems. The second set of studiesconstituting the bulk of the literature-concerns firm-level analysis in specific settings. Representing the first type of study, La Porta et al. (1998) construct a creditor rights index for 49 countries and find a weak but positive effect on the development of credit markets. Claessens and Klapper (2005) study bankruptcy codes in 35 countries and find that bankruptcies are more frequent in countries with both better judicial systems and stronger creditor rights. The authors reject the use of a single index, as they find that the occurrence of bankruptcy varies differently with specific rights. Djankov et al. (2006) present a novel approach to measure country-level bankruptcy characteristics. For 88 countries, they provide a case study of a defaulting hotel to local insolvency practitioners and ask what the consequences in their country would be. The authors construct a measure of the efficiency of debt enforcement based on detailed information about time, costs and outcomes. This measure is strongly related to financial development of a country including credit markets.

The analyses of Claessens and Klapper (2005) and Djankov et al. (2006) emphasize the importance of a country's bankruptcy system for its development. However, the characteristics of each country are captured in a single set of variables and related to country-level proxies for development. This type of analysis merely assesses the effects on economic development of the bankruptcy codes, not the mechanisms within the system. In the second set of studies, sets of defaulting firms are studied within a specific country, or in a limited number of countries. The empirical assessments involve two important characteristics, i.e. the direct cost ratio and the recovery rate. The direct cost ratio, defined as the ratio of costs over assets, measures the cost-efficiency of a system. The recovery rate, defined as the fraction 
of funds returned to creditors, proxies for the preservation of firm value for creditors in a system. Both measures are needed in order to assess the economic efficiency of a bankruptcy system. Table 1 provides an overview of the current empirical evidence.

In Table 1 we present the empirical evidence per country and distinguish reorganization and liquidation procedures. We show the period studied, number of observations, firm size, direct cost, the duration of the procedure and recovery rates. We report direct cost relative to book value of total assets, because realized asset value (proceeds of asset sales or the market value of the financial claims) are not always available. Table 1 shows cost ratios between $1.4 \%$ and $17.6 \%$ for the reorganization procedure in the US, Chapter 11 . For the UK relatively high cost ratios of $28 \%$ and $49 \%$ are reported, while the Finnish and Swedish costs range from $5.3 \%$ to $8.9 \%$. In general the costs are inversely related to the size of the firms in the sample, although the Scandinavian studies show relatively low cost ratios, given the average firm size. Table 1 also reports the time spent in bankruptcy proceedings. Time spent in bankruptcy may correlate with direct costs, i.e. the longer a case runs the higher direct costs will be. Although the studies on prepackaged bankruptcies show that shorter proceedings correlate with lower costs, the other studies only show that bankruptcy in general takes a lot of time (around 2.5 years) without the possibility to infer a general relationship between time and costs.

Eight studies report firm recovery rates and ten studies report recovery rates specifically for secured debt. Table 1 shows that the firm recovery rates range from a low of $21 \%$ to a high of $73 \%$. The lower recovery rates are found in liquidation procedures, while higher rates are to be found in studies on reorganizations, such as the US Chapter 11. This finding suggests that recovery rates are higher in reorganization procedures of reorganization-oriented systems. However, a simple comparison of recovery rates across bankruptcy systems is difficult for two reasons. First, a firm's size is likely to positively affect recovery rates and the US studies include relatively large firms. Second, a bias arises in the recording of the recovery rates attained under US Chapter 11 reorganizations due to over-continuation. This effect inflates the numerator in the recovery ratio and thus biases these rates systematically in a positive way. ${ }^{1}$

The 10 studies on recovery rates of secured creditors document higher rates than the firm recovery rates. The lowest recovery rate is found for liquidations $(51 \%)$ and the highest for reorganizations (99\%). Chapter 11 studies show that secured creditors may expect recovery to be in the range of $80 \%$ to $99 \%$. In the UK secured creditors may expect to receive $53 \%$ to $75 \%$. $^{2}$ For France, Davydenko and Franks (2005) find a percentage of $54 \%$, while the ratio is $64 \%$ for Germany. With respect

\footnotetext{
${ }^{1}$ Several authors indicate over-continuation in Chapter 11. For example, Hotchkiss (1995) finds poor post-performance, Gilson (1997) provides evidence of inadequate debt restructuring leading to overleverage, Jensen-Conklin (1992) finds evidence of a systematic failure of reorganization plans in smaller firms, and Bris et al. (2006) find that half of their Chapter 11 cases ultimately survive healthily after leaving the procedure.

2 Although Citron et al. (2003) do not classify the difference with the Franks and Sussman (2005) study as material (p. 157), the samples differ because Citron et al. study MBO's and Franks and Sussman study small and medium sized companies.
} 


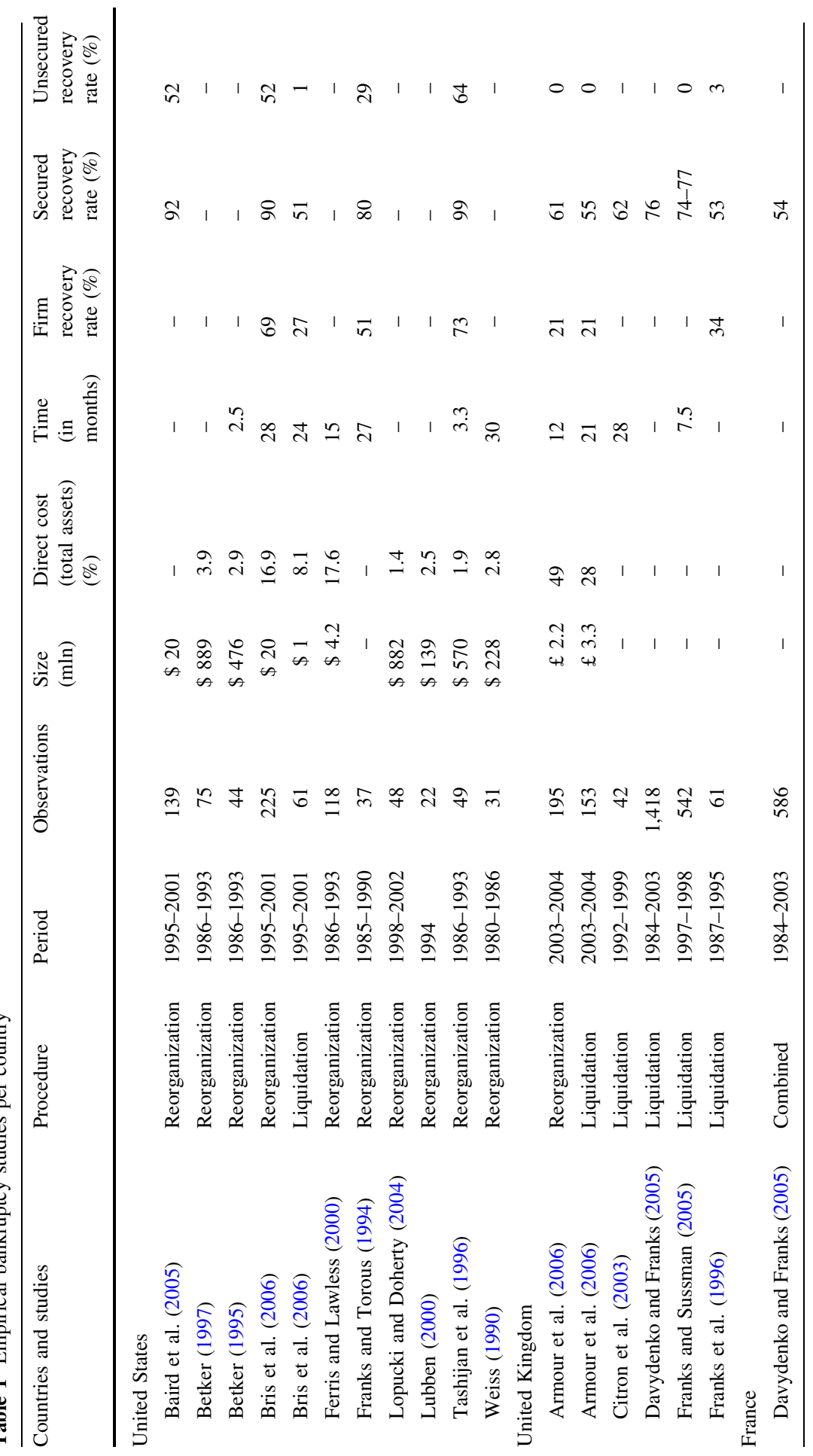




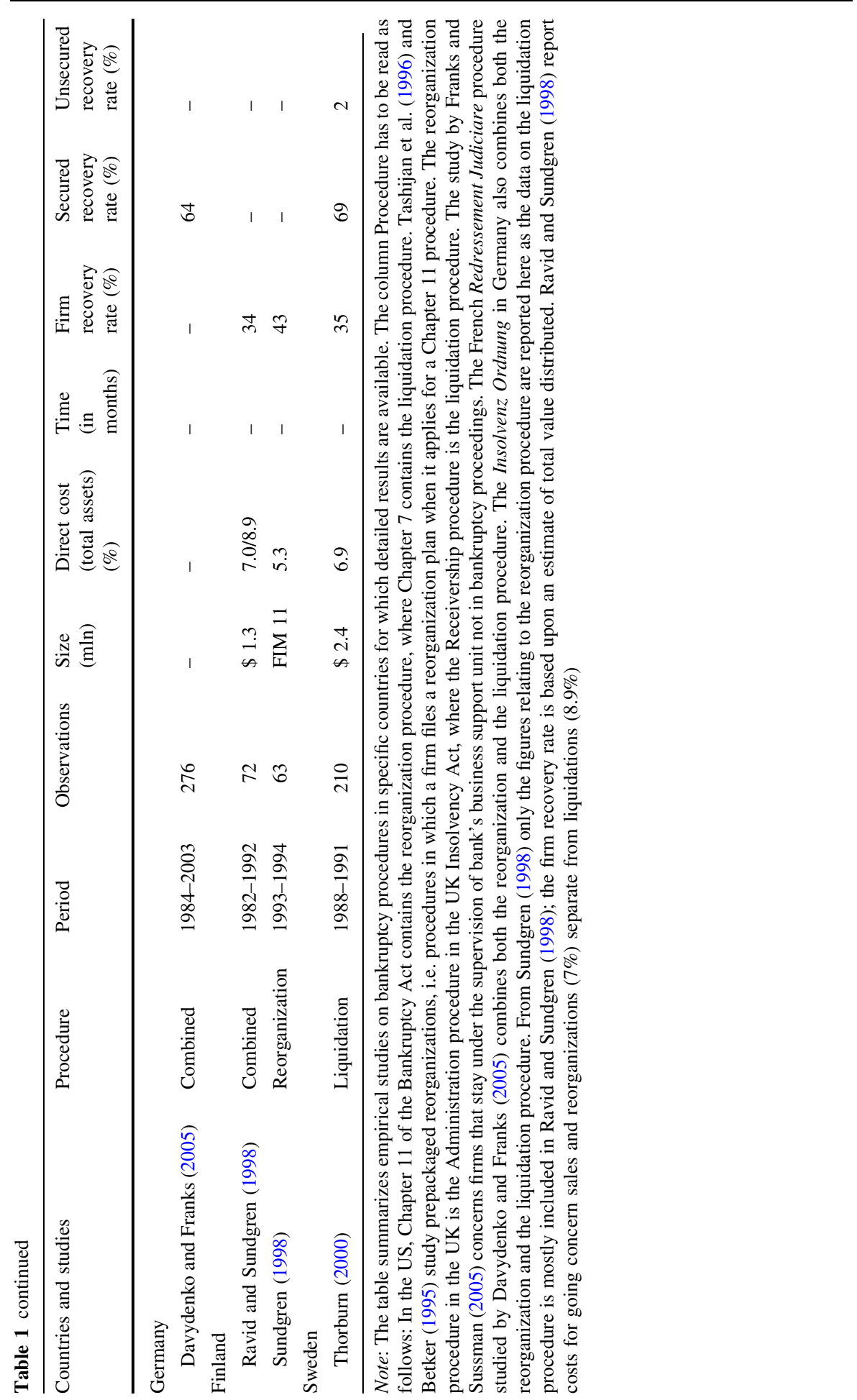


to the Scandinavian countries Thorburn (2000) finds a recovery rate for Sweden of $69 \%$.

\subsection{Bankruptcies in The Netherlands}

The Dutch bankruptcy law system is a liquidation-based system that can be characterized as an auctioning system, with a rudimentary reorganization provision (Couwenberg (2001)). ${ }^{3}$ This Dutch system provides two procedures, i.e. suspension of payment and bankruptcy. The suspension of payment procedure is aimed at firms in financial distress, but with sufficient prospects to recover economic health in a short time. The suspension procedure applies only to ordinary creditors and suspends all individual debt collection procedures by these creditors. Because secured and preferred creditors are not bound by the procedure, write-downs on secured and preferred claims need to be accepted voluntarily by these creditors. Within the suspension procedure the firm has to offer its ordinary creditors an agreement. The agreement rules do not apply to secured creditors and those holding preferred claims. The procedure ends as soon as the creditors accept the terms of the agreement. In case a firm fails in the procedure during a suspension of payment, it cannot opt to propose an agreement again in the bankruptcy procedure.

Both the firm and its creditors may petition for bankruptcy. At the start of the proceedings an independent trustee is appointed by the court and takes over the control of the incumbent management team. The trustee has a fiduciary responsibility to all creditors. The bankruptcy procedure provides the trustee the option to continue the operations of the firm. Since 1992, the firm is sheltered from its creditors by an automatic stay provision of up to 2 months. It can attract estate financing which will rank as an administrative expense claim, although the trustee may also offer unencumbered assets as security. The trustee organizes a sale of the assets, either piecemeal or going concern, by means of a private sale or a public auction. The proceeds of sales are to be distributed according to absolute priority rules, where administrative costs, estate financing and taxes accrued during the period of continuation in bankruptcy have priority over pre-bankruptcy debts. Secured pre-bankruptcy claims receive the proceeds of the sale of the collateral, where any unpaid part is treated as an unsecured claim. Next in line are audit claims, tax claims, wage claims, and-lastly-unsecured claims. ${ }^{4}$ Lastly, the bankruptcy code gives the trustee the power to annul transactions that classify as fraudulent. ${ }^{5}$

\footnotetext{
3 Our review is based on the law as it was for the bankrupt companies we study here. Recent changes are not discussed.

${ }^{4}$ In the Dutch legal setting a conflict may arise between the holder of a silent pledge and the Tax Authority over assets that are confined to the firm's compound. The conflict about these compound bounded assets is resolved either by the Tax Authority via an attachment of these assets, or by the pledge holder via conversion of the silent pedge into a possessory pledge.

5 The trustee is authorized to press charges against directors of companies in case evidence exists that these officers have failed their duties. Under specific conditions, directors may be held liable for any amount the estate is lacking. The most important reason for establishing this failure is to be found in inadequate administrative bookkeeping. Articles 2: 9, 10, 248 Civil Code.
} 


\section{Data and variables}

The study uses data from files of bankrupt companies in The Netherlands as maintained by trustees employed with law firms and regional court offices. These files are the only complete source for the balance sheets and profit and loss statements of the firm before bankruptcy and also include all transactions and procedures during bankruptcy including the final distribution of revenues. The files contain the legal, financial and operational details of the bankruptcy process. Below we describe our selection and data collection procedures.

From the court offices we obtained lists with the names of firms and appointed trustees for which the bankruptcy procedure had officially been terminated. The lists showed us which trustees and their corresponding law firms had an established insolvency practice. In selecting our cases we employed a size criterion based on debts and number of employees. Cases with debts of at least 500,000 Dutch guilders (equals $€ 227,000$ ) or at least 10 employees were included in the sample. We applied the size threshold, because this facilitates a comparison with existing studies and yields economically more interesting cases. We asked a subset of the law firms to co-operate with our research by giving their consent to access their archives on these completed bankruptcy cases. We exclusively included completed cases, because only in these cases a final settling of the claims could be provided for by the trustee. We could not include all cases on our list, for several reasons: archived files were not always timely retrievable, in-house office space was only available for a short period, or when a trustee had left the firm and the case was still open and thus had to take the files with him to his next employer. After visiting 35 law firms in eight court districts, we obtained access to 139 complete files. Due to outlier values we remove two observations from our sample. The majority of our cases come from three districts (Amsterdam, Arnhem and Utrecht). Our sample stretches over the period 1983-2000. More recent cases are somewhat over-represented in our sample (51 cases in 1983-1994 and 88 cases in 1995-2000).

Our data sources are balance sheets and income statements (both audited and concept reports), correspondence with/by the trustee, and reports of the trustee to courts. We filled out a structured data entry sheet for each firm, containing the name, legal form, ownership structure, causes of distress as noted by the trustee and details of the loan and security structures (including leasing). These data were retrieved from annual reports. We compared the amounts of debt outstanding in these annual reports with the amounts at the date of bankruptcy as reported by the trustee. In case of differences, we used the amounts reported by the trustee and adjusted the debts outstanding in the annual reports, because the trustee reports contained the most recent information. Next, characteristics on the process of resolving financial distress were noted, i.e. time taken for asset sales to complete, type of buyer, managerial involvement, employees laid off, involvement of prior lenders, length of automatic stay, conflicting rights on assets, procedures started and resolution of the bankruptcy procedure. Finally, we collected the pay-out on all the debts. Our final data set contains a rich set of characteristics of the 137 bankruptcy cases.

From the 137 firms in our sample, 38 firms (27.7\%) were liquidated piecemeal. The remaining firms continued their operations, either via a full going concern sale 
(79 firms), a partial going concern sale (9 firms), or via an agreement (11 firms). Table 2 provides an overview of the variables in our analysis, including detailed definitions of the variables.

We define the direct costs as out-of-pocket expenses during the period that the bankruptcy procedure is open. It includes the fees paid to the trustee(s) and other advisers plus the costs associated with the proceeding itself. We scale the direct costs with realized proceeds. The firm recovery rate is defined as the total pay-outs to all creditors, scaled by the sum of pre-bankruptcy and estate debts. Similarly, the bank debt recovery rate is the pay-out to the bank over the bank loans outstanding before bankruptcy. In our sample, a subset of 114 firms had bank loans. Therefore, the analysis on bank recovery rates is performed for this sub sample and we separately provide summary statistics for these firms.

The size of the firm is measured by total assets (TotAssets). The asset structure is proxied by the variable FixedAssets, which is the value of fixed assets over total assets. As a measure for liquidity, we include the quick ratio (QuickRatio). The indebtedness of the company is measured by the total amount of debt relative to total assets (Debt). Specifically for bank debt, we define BankDebt as bank debt over total liabilities. In case bank debt is present we measure secured bank debt as the nominal book value of collateral scaled by the nominal value of the bank loans (SecBankDebt). As a proxy for operational profitability we include a dummy variable with a value of one in case a firm has a positive return on assets, and zero otherwise (PosROA). The above-mentioned variables are measured on the basis of the annual report in the year preceding the start of the bankruptcy procedure.

Several variables describe the bankruptcy process. The number of months the bankruptcy procedure takes is denoted as TimeProc. The dummy variable DirSellAssets has a value of one in case the assets are sold directly by the opening of the procedure, and zero otherwise. ${ }^{6}$ The variable TimeSellAssets is defined as the number of months between the start of the procedure and the sale of the assets. The number of buyers is a proxy for a situation of competitive bidding in an asset sale (NrBuyers). The variable DebtorFiling has a value of one if the debtor files, and zero otherwise. The trustee may decide to continue the operational activities, or decide to cease the operations; we include the dummy variable ContInBnkr with a value of one, in case the trustee decides to continue the operations in bankruptcy, and zero otherwise. The conflict that may arise between the holder of a silent pledge and the Tax Authority over the compound bounded assets, is measured using a dummy variable. The dummy variable ConflictCBA has a value of one in case of a conflict, and zero otherwise. We also include a dummy variable with a value of one for procedures started by the trustee (ProcT), and zero otherwise. We include the number of disputes the trustee has to settle (NrDisputes). Two variables capture the stay period. The dummy variable Stay measures whether (value is one) or not (value is zero) a stay has been imposed. The variable StayPeriod measures the number of months of the stay, which is legally bound to 2 months. We include the economic outcome of the procedure: whether or not the firm is liquidated piecemeal. The

\footnotetext{
${ }^{6}$ In practice, this sale takes some days as the trustee has to check whether the firm is actually owner of the assets before the actual transfer can take place.
} 
Table 2 Definitions of variables and summary statistics

\begin{tabular}{|c|c|c|c|}
\hline Variable name & Variable description & Full sample & $\begin{array}{l}\text { Bank loan } \\
\text { sample }\end{array}$ \\
\hline \multicolumn{4}{|c|}{ Costs and recovery rates } \\
\hline DirectCosts & $\begin{array}{l}\text { Out-of-pockets expenses during bankruptcy } \\
\text { procedure, scaled by realized proceeds }\end{array}$ & $0.160(0.112)$ & $0.137(0.094)$ \\
\hline FirmRecovery & $\begin{array}{l}\text { Total pay-out to creditors, scaled by debts before } \\
\text { the bankruptcy (including estate debts) }\end{array}$ & $0.372(0.326)$ & $0.372(0.334)$ \\
\hline BankRecovery & $\begin{array}{l}\text { Pay-out to banks, scaled by bank debts before } \\
\text { the bankruptcy }\end{array}$ & - & $0.800(0.995)$ \\
\hline \multicolumn{4}{|l|}{ Firm characteristics } \\
\hline TotAssets & $\begin{array}{l}\text { Book value of total assets (in 1,000 Dutch } \\
\text { guilders) }\end{array}$ & $10.445(2.652)$ & $11.936(2.988)$ \\
\hline FixedAssets & $\begin{array}{l}\text { Ratio of book value of fixed assets and book } \\
\text { value of total assets }\end{array}$ & $0.373(0.342)$ & $0.377(0.342)$ \\
\hline QuickRatio & $\begin{array}{l}\text { Ratio of current assets minus inventory and } \\
\text { current liabilities }\end{array}$ & $0.560(0.408)$ & $0.551(0.418)$ \\
\hline Debt & $\begin{array}{l}\text { Ratio of long-term plus short-term liabilities and } \\
\text { book value of total assets }\end{array}$ & $2.081(1.484)$ & $2.064(1.434)$ \\
\hline BankDebt & $\begin{array}{l}\text { Ratio of long-term plus short-term bank debt and } \\
\text { total liabilities }\end{array}$ & $0.241(0.214)$ & $0.290(0.239)$ \\
\hline SecBankDebt & $\begin{array}{l}\text { Ratio of nominal book value of assets securing } \\
\text { bank loans and bank debt }\end{array}$ & - & $2.509(1.837)$ \\
\hline PosROA & $\begin{array}{l}\text { Dummy variable with value of one if pre-tax } \\
\text { return on assets is positive, and zero otherwise }\end{array}$ & $0.613(1)$ & $0.588(1)$ \\
\hline \multicolumn{4}{|c|}{ Procedural characteristics } \\
\hline TimeProc & Time in bankruptcy procedure in months & $25.044(18.641)$ & $25.995(18.510)$ \\
\hline DirSellAssets & $\begin{array}{l}\text { Dummy variable with value of one if assets are } \\
\text { sold directly upon opening of bankruptcy } \\
\text { procedure, and zero otherwise }\end{array}$ & $0.723(1)$ & $0.728(1)$ \\
\hline TimeSellAssets & Time it takes to sell assets in months & $3.387(1.000)$ & $3.465(1.000)$ \\
\hline NrBuyers & $\begin{array}{l}\text { Number of prospective buyers of the assets of } \\
\text { the firm }\end{array}$ & $2.291(1)$ & $2.404(1)$ \\
\hline DebtorFiling & $\begin{array}{l}\text { Dummy variable with value of one if firm files } \\
\text { bankruptcy petitioning itself, and zero } \\
\text { otherwise }\end{array}$ & $0.569(1)$ & $0.588(1)$ \\
\hline ContInBnkr & $\begin{array}{l}\text { Dummy variable with value of one if activities } \\
\text { of firm are continued during bankruptcy, and } \\
\text { zero otherwise }\end{array}$ & $0.467(0)$ & $0.482(0)$ \\
\hline ConflictCBA & $\begin{array}{l}\text { Dummy variable with value of one if conflicting } \\
\text { rights exists on compound bounded assets, and } \\
\text { zero otherwise }\end{array}$ & $0.409(0)$ & $0.482(0)$ \\
\hline ProcT & $\begin{array}{l}\text { Dummy variable with value of one if trustee } \\
\text { decides to start a procedure, and zero } \\
\text { otherwise }\end{array}$ & $0.270(0)$ & $0.289(0)$ \\
\hline NrDisputes & Number of disputes in bankruptcy & $1.036(1)$ & $1.009(1)$ \\
\hline Stay & $\begin{array}{l}\text { Dummy variable with value of one if supervising } \\
\text { judge orders a stay, and zero otherwise }\end{array}$ & $0.321(0)$ & $0.351(0)$ \\
\hline
\end{tabular}


Table 2 continued

\begin{tabular}{|c|c|c|c|}
\hline Variable name & Variable description & Full sample & $\begin{array}{l}\text { Bank loan } \\
\text { sample }\end{array}$ \\
\hline StayPeriod & $\begin{array}{l}\text { Time in stay period in months (maximum of } \\
\text { two) }\end{array}$ & $0.401(0)$ & $0.447(0)$ \\
\hline Liquidation & $\begin{array}{l}\text { Dummy variable with value of one if firm's } \\
\text { assets are liquidated piecemeal, and zero } \\
\text { otherwise }\end{array}$ & $0.277(0)$ & $0.289(0)$ \\
\hline SharesMan & $\begin{array}{c}\text { Fraction of shares management get in venture } \\
\text { taking over the assets of the bankrupt firm }\end{array}$ & $11.854(0.000)$ & $10.956(0.000)$ \\
\hline
\end{tabular}

Note: This table provides the abbreviations, definitions, averages and medians of the variables in our data set. The column denoted 'Full sample' contains the statistics of all 137 observations in the sample. The column denoted 'Bank loan sample' contains the statistics for a sub sample of 114 observations where the bank debt is above zero. We present in each cell the average and median (in parentheses)

dummy variable Liquidation has a value of one in liquidations and is zero for going concern sales and agreements. Finally, we measure the fraction of shares the management obtains of the firm that buys the bankrupt firm (SharesMan).

\section{Empirical results}

In this part of the paper we analyze the firms on direct costs and recovery rates. We proceed as follows. First, we give an overview of the summary statistics of the relevant variables (Sect. 4.1). Second, we present our hypothesis and regression results for direct costs (Sect. 4.2), firm recovery rates (Sect. 4.3) and bank recovery rates (Sect. 4.4). We run cross-sectional ordinary least squares regressions. We first measure the influence of the firm characteristics, second the effect of the time it takes to resolve bankruptcy, third, process characteristics and fourth, we run a regression with the statistically significant variables.

\subsection{Summary statistics}

Table 2 provides the summary statistics of the variables. The column with the full sample contains the averages and medians per variable. In the column for the bank loan sample we provide these statistics for the 114 observations with bank debt. The average direct costs are $16.0 \%$ of the realized proceeds of the bankruptcy procedure. $^{7}$ The median value of $11.2 \%$ and the values in the bank loan sub sample (average of $13.7 \%$ and median of $9.4 \%$ ) are relatively close to this percentage. The average firm recovery rate is $37.2 \%$ of total debts. This implies that creditors lose on average $62.8 \%$ of the nominal outstanding debt, i.e. the original debt investments minus prior amortizations. The bank recovery rate is strikingly different. On average $80.0 \%$ of the value of bank loans is recovered. The median of $99.5 \%$ shows that the average is influenced by a small number of low recoveries. In fact, $59.6 \%$ of the

\footnotetext{
7 Based on the book value of assets, the average direct cost in our sample amounts to $10.7 \%$.
} 
observations have a recovery above $90 \% ; 22.8 \%$ have a recovery between $50 \%$ and $90 \%$; and $17.5 \%$ have a recovery below $50 \%$.

The average size of the firms in the sample is 10 million Dutch guilders (€4.54 million), while the median is 2.7 million Dutch guilders. The firms have on average $37.3 \%$ fixed assets and the average quick ratio is only 0.560 . The firms are heavily indebted, as the mean debt ratio is 2.081 . In other words, on average the amount of debt is twice the asset value. In the firms with bank debt, this form of debt is $29.0 \%$ of total debts. The bank debt is well-secured, because the average size of the collateral is 2.5 times the bank debt. Clearly, on average the banks are extremely careful and require substantial collateral. In our regression analyses, we test whether this conservatism helps in recovering debts. In the book year before the bankruptcy $61.3 \%$ of the firms have a positive operating return.

The remaining variables in Table 2 summarize the use of legal bankruptcy procedures in The Netherlands. On average the firms in our sample spend 25 months in the bankruptcy procedures. In $72.3 \%$ of the cases assets are sold directly after the procedure has started. On average, it takes 3.4 months to sell the assets. The average number of buyers involved in the sale is 2.291 , while the median is one. In $46.7 \%$ of the firms, the activities are continued during the procedure. We find conflicting rights on compound bounded assets in $40.9 \%$ and procedures started by the trustee in $27.0 \%$ of the cases. The average number of disputes is 1.036 . In $32.1 \%$ of the cases a stay period of 1 or 2 months is allowed, while the average number of months of the stay is 0.401 . This implies that $8 \%$ of the firms have the extended stay period of 2 months. ${ }^{8}$ The outcome of the procedure is liquidation in $27.7 \%$ of the cases. On average, the new management gets $11.9 \%$ of the shares. However, this statistic is driven by 19 cases with a non-zero stake. 9

\subsection{Direct costs}

Our first set of regression tests aims to explain the relative direct costs. Table 3 contains the hypotheses and the regression results.

Table 3 provides the results of four regression models, relating the explanatory variables to direct costs as percentage of total realized proceeds. In model (1) we run regressions of firm characteristics on direct costs. With respect to size, we presume that bankruptcy costs have a large fixed component. This leads to the hypothesis that firm size has a negative effect on relative costs. Because we expect that the marginal influence of size decreases, we apply a log-scaling. The regression coefficient for total assets is negative as hypothesized and the coefficient is significant at the $1 \%$ level. To illustrate the effect of size, we calculate the difference between the logarithms of total assets of the 25 and 75 th percentile. Asset size changes from 940,000 to $7,740,000$ and the difference of the logarithms is 0.916 . This implies that the costs decrease by $4.4 \%$ points $(0.916$ times -0.048$)$ when firm size changes

\footnotetext{
${ }^{8}$ In case all firms with a stay would have a stay period of 1 month, the average number of months would be 0.321 . Since the number of months can be two and the average is 0.401 , the number of firms with a stay period of 2 months must be $0.401-0.321$, or $8 \%$.

9 The average of the stakes in these 19 cases is $85.5 \%$.
} 


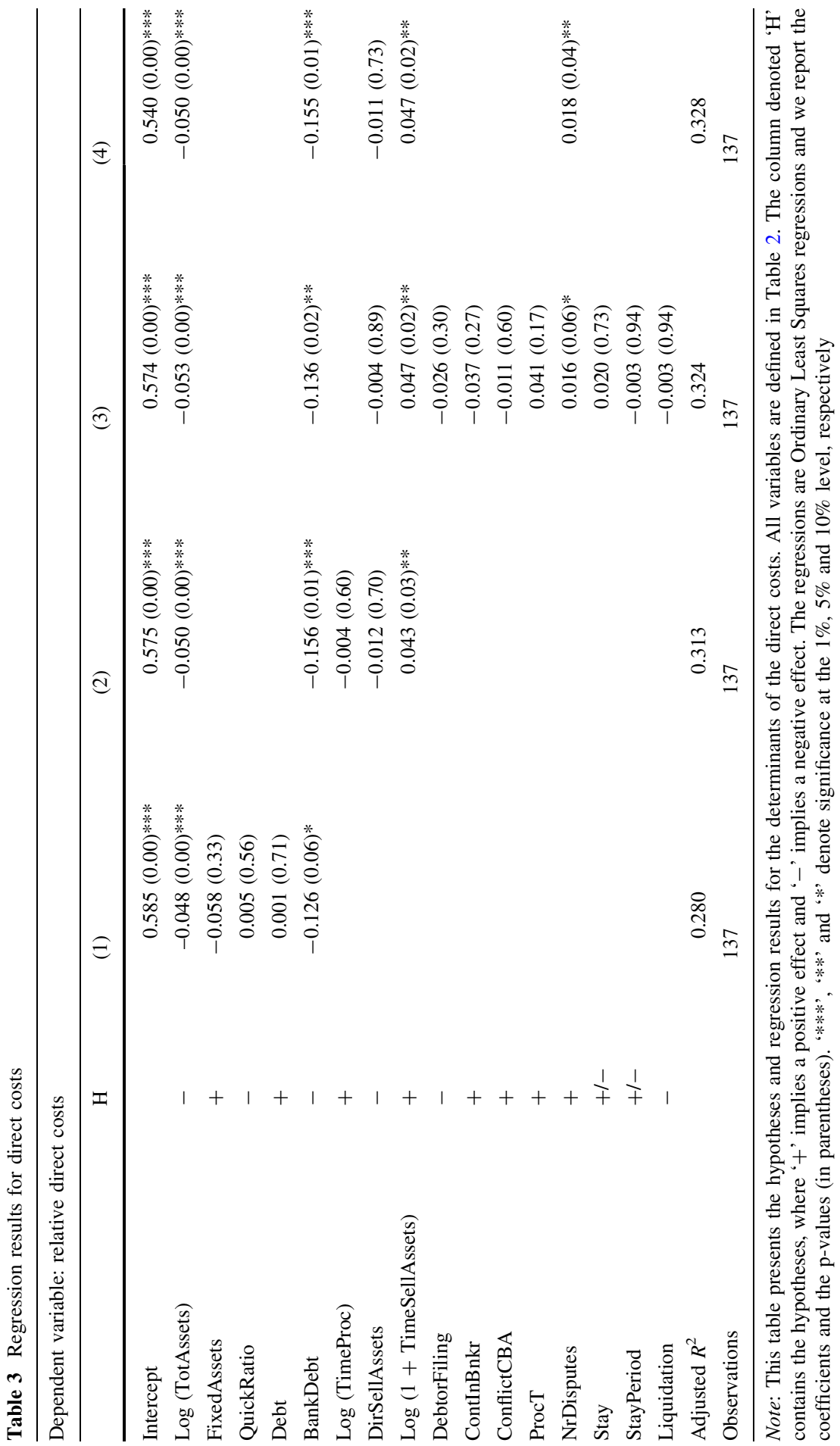


from the 25 to the 75 th percentile. The fraction of fixed assets, the quick ratio and debt are insignificant. Relative bank debt is significant at the $10 \%$ level and has the hypothesized sign. Bank debt is expected to save on costs, because the higher relative bank debt, the less the trustee will have to deal with other creditors than the bank. Economically this effect is also significant, as $1 \%$ more bank debt reduces relative costs by $0.126 \%$ points. We are glad to notice that the adjusted $R^{2}$ of the model is as high as 0.28 , which is an excellent fit for a cross-sectional regression.

In model (2), we include variables for the length of the procedure and we omit insignificant variables in model (1). ${ }^{10}$ Obviously, we hypothesize that the time in months has a positive effect on costs. Again, as we expect that the marginal influence of time decreases, we apply a log-scaling. Our presumption regarding the dummy variable DirSellAssets, indicating whether assets are sold directly, is that this lowers costs. However, if this sale takes more time (TimeSellAssets) the trustee needs to spend more effort selling these assets, and thus costs are expected to rise. It is interesting to find that the coefficient of TimeProc is insignificant. The implication is that, although Dutch bankruptcies may take many months, costs are independent of the length of the procedure, after controling for firm size, bank debt and the time it takes to sell assets. Thus, as we find that the variable TimeSellAssets is significant on 5\% level and has the predicted sign, we conclude that direct costs are dependent on the effort and time it takes to sell the assets of the firm and not on the period of time that the bankruptcy procedure is running. The most plausible explanation for this finding is that the total procedure time includes substantial periods of non-activity, while this does not hold for the periods during which assets are sold.

In model (3) we add additional variables for the legal procedures. Filing by the debtor, continuation in bankruptcy, conflicting creditor rights and procedures started by the trustee all turn out to have insignificant impacts on costs. This implies that in the Dutch legal setting these procedures do not lead to measurable inefficiencies. The number of disputes has a positive effect on costs and the coefficient is significant on the $5 \%$ level. More disputes by creditors give rise to additional costs. The automatic stay variables both are insignificant, implying that these do not give rise to additional costs. The effect of the piecemeal liquidation dummy is insignificant, which indicates that no costs savings are to be expected in a liquidation situation. It is interesting to notice that the adjusted $R^{2}$ changes from 0.280 in model (1) to 0.324 in model (3). This result stresses that the firm characteristics in model (1) have superior explanatory power, in comparison with the legal procedure variables that are added in model (3). In model (4) we include the significant variables from previous models and the dummy for direct sales, because this variable is related to the time to sell assets. The results show that the effects are robust and that the adjusted $R^{2}$ of the model improves to 0.328 .

In summary, our results for the determinants of direct bankruptcy costs show that firm size and bank debt have a negative effect on the costs. On the other hand, a

\footnotetext{
${ }^{10}$ A potential disadvantage of omitting insignificant variables is that in alternative specifications these variables turn out to be significant. In order to overcome this problem, we add in the final specification each of the omitted variables separately to test for significance. We find no cases in Tables 3 and 4 of 5 where omitted variables turn significant in alternative specifications.
} 
Table 4 Regression results for firm recovery rates

\begin{tabular}{|c|c|c|c|c|c|}
\hline \multicolumn{6}{|c|}{ Dependent variable: firm recovery rate } \\
\hline & $\mathrm{H}$ & (1) & (2) & (3) & (4) \\
\hline Intercept & & $0.326(0.01)^{* * *}$ & $0.204(0.00)^{* * *}$ & $0.285(0.00)^{* * * *}$ & $0.231(0.00)^{* * *}$ \\
\hline Log (TotAssets) & + & $-0.013(0.40)$ & & & \\
\hline FixedAssets & + & $0.169(0.02)^{* *}$ & $0.165(0.03)^{* *}$ & $0.128(0.09)^{*}$ & $0.139(0.04)^{* *}$ \\
\hline QuickRatio & + & $0.082(0.01)^{* * *}$ & $0.079(0.01)^{* * *}$ & $0.094(0.00)^{* * *}$ & $0.092(0.00) * * *$ \\
\hline Debt & - & $-0.019(0.09)^{*}$ & $-0.017(0.11)$ & $-0.018(0.05)^{*}$ & $-0.017(0.07)^{*}$ \\
\hline BankDebt & + & $0.313(0.01)^{* *}$ & $0.256(0.02)^{* *}$ & $0.229(0.05)^{*}$ & $0.227(0.04)^{* *}$ \\
\hline PosROA & + & $0.006(0.85)$ & & & \\
\hline Log (TimeProc) & - & & $0.003(0.76)$ & & \\
\hline DirSellAssets & + & & $0.023(0.62)$ & & \\
\hline $\begin{array}{l}\log (1+ \\
\quad \text { TimeSellAssets })\end{array}$ & - & & $0.014(0.64)$ & & \\
\hline DebtorFiling & + & & & $-0.027(0.43)$ & \\
\hline ContInBnkr & + & & & $0.081(0.04)^{* *}$ & $0.075(0.04) * *$ \\
\hline NrBuyers & + & & & $0.002(0.69)$ & \\
\hline ConflictCBA & - & & & $-0.027(0.41)$ & \\
\hline ProcT & - & & & $0.007(0.83)$ & \\
\hline NrDisputes & - & & & $-0.017(0.29)$ & \\
\hline Stay & + & & & $-0.019(0.80)$ & \\
\hline StayPeriod & + & & & $-0.0205(0.68)$ & \\
\hline Liquidation & - & & & $-0.061(0.09)^{*}$ & $-0.064(0.06)^{*}$ \\
\hline SharesMan & + & & & $-0.0001(0.87)$ & \\
\hline Adjusted $R^{2}$ & & 0.250 & 0.247 & 0.281 & 0.303 \\
\hline Observations & & 137 & 137 & 137 & 137 \\
\hline
\end{tabular}

Note: This table presents the hypotheses and regression results for the determinants of the firm recovery rates. All variables are defined in Table 2. The column denoted ' $H$ ' contains the hypotheses, where ' + ' implies a positive effect and '-' implies a negative effect. The regressions are Ordinary Least Squares regressions and we report the coefficients and the p-values (in parentheses). '***', '**' and '*' denote significance at the $1 \%, 5 \%$ and $10 \%$ level, respectively

longer time to sell assets and a larger number of disputes lead to higher costs. These results are in line with the hypotheses. Thorburn (2000) and Sundgren (1998) also document a similar effect of firm size. Thorburn finds that the length of the procedure is a significant determinant of costs, while we document that the period needed to sell assets matters more.

\subsection{Firm recovery rates}

In this section we report regression analyses of firm recovery rates on firm characteristics and procedural characteristics in order to measure which elements in a liquidation-based system are likely to positively influence recovery rates. Table 4 describes the hypotheses and the regression results. 
In Table 4, model (1) includes the influence of firm characteristics and shows that the value of total assets is negatively related to the firm recovery rate, but the coefficient is insignificant. Both asset structure variables, fraction of fixed assets and quick ratio, have significantly positive coefficients. The fraction of fixed assets is likely to have a positive sign, because it is a proxy for saleable assets and also inversely related to intangible assets. For the quick ratio we also hypothesize a positive effect on recovery, because companies with more liquid assets have a higher recovery potential. Obviously, for leverage (Debt) we predict a negative coefficient, as more indebted firms have simply more debt to recover. However, we hypothesize a positive effect of bank debt, because banks will put in more effort in the recovery process in case their part of the total liabilities is larger. The estimates corroborate our hypothesized effects. Particularly, the coefficient of bank debt of 0.313 is high. In case a firm has the median amount of bank debt of $21.4 \%$, the recovery rate is $6.7 \%$ point $(21.4$ times 0.313$)$ higher, in comparison with a firm without bank debt. The adjusted $R^{2}$ of the model is 0.250 .

In model (2) we drop insignificant variables and include time-related variables. None of these variables obtain significance. Clearly, both the length of the bankruptcy process and the time to sell assets do not influence the recovery rates. In model (3), we introduce the procedural characteristics. Continuation in bankruptcy is hypothesized to be positive for the recovery rate, because it indicates that the firm has valuable activities, which may yield higher asset prices. The liquidation dummy is expected to yield a negative coefficient, because realized values are normally lower in piecemeal liquidations, compared to going concern asset sales. We find that the variables continuation in bankruptcy and piecemeal liquidation are significant, respectively at $5 \%$ and $10 \%$ level. Both coefficients also have the hypothesized sign. The levels of the coefficients imply that the recovery rate increases by $8.1 \%$ point when the trustee continues the operations and decreases by $6.1 \%$ point in case of liquidation. Given that the average recovery rate is $37.2 \%$, these two variables have a major impact on the creditors' proceeds. Conflicts, procedures and disputes do not affect recovery rates, nor does the involvement of management. The adjusted $R^{2}$ in model (3) is 0.281 , which again indicates a minor improvement relative to the firm characteristics in model (1). In model (4) we include only the significant variables in previous models and find that the results are robust.

We find that the firm recovery rate is higher when firms have more fixed assets, a higher quick ratio, are not liquidated and continue their operations in bankruptcy. These results are in line with expectations. We also find that the effect on recovery is negative for leverage and positive for bank debt. Our results confirm previous tests. Thorburn (2000) documents that recovery rates in Swedish firms are influenced by secured (bank) debt and the outcome of the procedure. Sundgren (1998) finds that indebtedness is a significant determinant of recovery. Bris et al. (2006) report similar results with respect to size (not or only weakly relevant), leverage and secured debt. Gilson et al. (1990) report that distressed exchange offers in the US are more successful when the debt structure is more concentrated, which is in line with our result for bank debt. The results show that even in liquidation-based system it helps to have concentrated bank debt. 
Table 5 Regression results for bank debt recovery rates

\begin{tabular}{|c|c|c|c|c|c|}
\hline \multicolumn{6}{|c|}{ Dependent variable: bank debt recovery rate } \\
\hline & $\mathrm{H}$ & (1) & (2) & (3) & (4) \\
\hline Intercept & & $1.219(0.00)^{* * *}$ & $1.161(0.00)^{* * *}$ & $1.194(0.00)^{* * *}$ & $1.158(0.00)^{* * *}$ \\
\hline Log (TotAssets) & + & $-0.046(0.05)^{*}$ & $-0.041(0.03)^{* *}$ & $-0.054(0.01)^{* * *}$ & $-0.046(0.02)^{* *}$ \\
\hline FixedAssets & + & $-0.136(0.28)$ & & & \\
\hline QuickRatio & + & $-0.008(0.79)$ & & & \\
\hline Debt & - & $-0.031(0.00)^{* * *}$ & $-0.028(0.00)^{* * *}$ & $-0.031(0.00)^{* * *}$ & $-0.029(0.00)^{* * *}$ \\
\hline BankDebt & - & $0.126(0.50)$ & & & \\
\hline SecBankDebt & + & & $0.035(0.07)^{*}$ & $0.026(0.09)^{*}$ & $0.031(0.08)^{*}$ \\
\hline PosROA & + & $0.064(0.25)$ & & & \\
\hline Log (TimeProc) & - & & $-0.008(0.59)$ & & \\
\hline DirSellAssets & + & & $-0.059(0.43)$ & & \\
\hline $\begin{array}{l}\log (1+ \\
\quad \text { TimeSellAssets })\end{array}$ & - & & $0.003(0.94)$ & & \\
\hline DebtorFiling & + & & & $0.109(0.06)^{*}$ & $0.089(0.10)^{*}$ \\
\hline ContInBnkr & + & & & $0.036(0.53)$ & \\
\hline NrBuyers & + & & & $0.000(0.99)$ & \\
\hline ConflictCBA & - & & & $0.044(0.44)$ & \\
\hline ProcT & 0 & & & $-0.014(0.83)$ & \\
\hline NrDisputes & 0 & & & $0.029(0.12)$ & \\
\hline Stay & + & & & $-0.306(0.03)^{* *}$ & $-0.266(0.05)^{*}$ \\
\hline StayPeriod & + & & & $0.204(0.03)^{* *}$ & $0.173(0.04)^{* *}$ \\
\hline Liquidation & - & & & $-0.162(0.02)^{* *}$ & $-0.135(0.03) * *$ \\
\hline SharesMan & + & & & $-0.002(0.13)$ & \\
\hline Adjusted $R^{2}$ & & 0.078 & 0.131 & 0.205 & 0.203 \\
\hline Observations & & 114 & 114 & 114 & 114 \\
\hline
\end{tabular}

Note: This table presents the hypotheses and regression results for the determinants of the bank debt recovery rates. All variables are defined in Table 2. The column denoted ' $H$ ' contains the hypotheses, where ' + ' implies a positive effect, ' - ' implies a negative effect and ' 0 ' implies no effect. The regressions are Ordinary Least Squares regressions and we report the coefficients and the p-values (in parentheses). ' $* * *$ ', ' $* *$ ' and ' $*$ ' denote significance at the $1 \%, 5 \%$ and $10 \%$ level, respectively

\subsection{Bank debt recovery rates}

In this section we focus our attention on a specific type of debt, i.e. bank debt. Banks were involved as creditors in a sub sample of 114 firms. For this sample we test for the determinants of the recovery rate of the bank debt. Table 5 provides the hypotheses and regression results.

Table 5 includes the same variables as present in the analyses on the firm recovery rate. Regression model (1) includes the firm characteristics. Total assets yields a negative coefficient that is significant at the $10 \%$ level, indicating that the larger firms in our sample yield a lower bank debt recovery ratio. This finding 
contrasts with the hypothesis. ${ }^{11}$ The two variables for asset structure have insignificant coefficients. As hypothesized, the debt ratio has a negative impact on the bank's recovery rates, a result that is significant at the $1 \%$ level. The portion of bank debt does not have a significant coefficient. The dummy for a positive return is also insignificant. In model (2) we eliminate the insignificant variables from model (1) and add the secured bank debt and the time variables. The variable for the secured bank debt yields a positive coefficient, which is significant at the $10 \%$ level. A plausible explanation for this effect is the absence of the effects for fixed assets and the quick ratio, which were present in the firm recovery regressions. In the discussion of the summary statistics we have noticed that the bank debt is well-secured, as the collateral is on average 2.5 times the bank's debt. Clearly, the collateral helps the bank in recovering their loans. ${ }^{12}$ The three coefficients for the length of the procedure, including the time to sell assets, are insignificant.

Model (3) takes up the procedural variables. In case the debtor files for bankruptcy the bank's recovery rate is significantly higher. The dummy for the automatic stay is negative and significant (5\% level), while the period of the stay is positively significant $(5 \%$ level). Because the stay period can be absent, 1 or 2 months, this result should be interpreted as follows. The base situation is no stay, where both variables have a value of zero. In case of a one-month stay, Stay equals one and StayPeriod equals one, leading to an aggregate effect of -0.102 $(-0.306+0.204)$. In case of an extended stay of 2 months, StayPeriod becomes two, yielding a joint influence of $0.102(-0.306+2 \times 0.204)$. It should be noted that the summary statistics show that $24.1 \%$ of the bankruptcies have a one-month stay period, while only $8.0 \%$ has the extended stay. The liquidation dummy is significantly negative at the $5 \%$ level. The size of the coefficient implies that liquidated firms have a $16.2 \%$ point lower recovery for the bank. In order to assess the added explanatory power from procedural variables, we compare model (2) and model (3). The explanatory power of the model (3) is 0.205 , which is higher than the 0.131 in model (2). Apparently, legal procedures have a strong effect on the banks' recovery rates. Regression model (4) confirms the result of the third model, without any major change in significance of variables.

The results for the bank debt recovery rates show the recovery is lower when firms are larger, more indebted or liquidated. Collateral underlying the bank debt indeed boosts recovery rates. Moreover, when the firm itself files for bankruptcy, the recovery for the bank is higher. The impact of the stay period is ambiguous: the $24.1 \%$ of the cases with a one-month stay period are worse off, while the $8.0 \%$ with the extended stay have a higher recovery. In comparison with the firm recovery rate,

\footnotetext{
${ }^{11}$ In order to facilitate a comparison with the results for the firm recovery rate, we re-estimated the regressions in Table 4 with the sub sample of 114 firms with bank debt. We find that all significant findings in Table 4 remain present in the sample of 114. In addition, Log (TotAssets) and SharesMan become significant, both with a negative sign.

12 An interesting issue is whether banks are overcareful in their collateral requirements. Since a firm's collateral potential is limited, overcareful banks may hamper additional borrowing and thus firm growth. A further analysis of this issue is beyond the scope of our data, because a test would require borrowing, collateral and investment data from both distressed and non-distressed firms.
} 
leverage and liquidation have the same effects, i.e. negative. The asset structure influences both recoveries in different ways: fixed assets and quick ratio matter for all creditors, while secured assets matter for the bank.

\section{Conclusions}

Chapter 11, the reorganization provision in the US Bankruptcy Code, has been a major inspiration in various degrees to European policy makers. Belgium, Finland, France, Germany and the UK changed their respective bankruptcy law systems only fairly recently. ${ }^{13}$ In all these countries the main reason for change was a lack in the reorganization power of the respective systems. The liquidation-based origins of these European laws were considered out of date, and more importantly to lead to over-liquidation. Given this proposition, it is amazing to find so little empirical research in these countries trying to substantiate this claim. This paper is an attempt to come to a more balanced view on reorganization and liquidation in liquidationbased bankruptcy system.

We provide evidence on the direct costs and the recovery rates of small and medium-sized Dutch bankrupt firms. The Dutch bankruptcy system is a liquidating auction system and is in large measure equivalent to for instance the Swedish bankruptcy law and the pre-1993 Finnish bankruptcy law (see Thorburn 2000; Ravid and Sundgren 1998). We employ a unique data set, which includes details of firm characteristics and of the bankruptcy process and outcomes.

In the Dutch system, assets of the firm are sold by the trustee who takes over the control over the firm on the declaration date. Assets are sold quickly, on average in 3.4 months. The procedure itself takes much longer, 25 months on average. The direct costs of the procedure are $16 \%$ of the total realized asset value. This compares to the finding of Thorburn (2000) in liquidation-based systems and to the findings of Bris et al. (2006) and Ravid and Sundgren (1998) on direct costs (when using book value of assets). Our regression analyses show that direct costs are negatively related to firm size and bank debt and positively to the time it takes to sell assets and the number of disputes in bankruptcy. These results indicate that bankruptcy costs in The Netherlands have a fixed component and that it saves costs to have a large (bank) creditor. We conclude that firm characteristics are the main determinants of bankruptcy resolution, while the specific Dutch legal procedures in the bankruptcy process matter to a minor extent.

Next, we analyze firm recovery rates and bank debt recovery rates. Firm recovery rates are on average $37 \%$ of the total debt outstanding before the bankruptcy. This recovery rate is similar to the one found by Thorburn (2000) and Franks and Torous (1994). Nevertheless, they fall short of the rates as reported for prepackaged Chapter 11 procedures of $73 \%$ as reported by Tashijan et al. (1996) and Bris et al. (2006) for their Chapter 11 cases. Our finding gives support for the argument that in

\footnotetext{
13 See Couwenberg (2001) for a short overview. Belgium changed its rules in 1998, France's latest change was in 1994, Finland 1993, Germany in 1999 (effective, the law changed in 1994), the UK in 2002. Currently, the Dutch government is also working on a modernization of Dutch Bankruptcy Law.
} 
liquidation-based systems it is the asset side that is fairly quickly resolved from financial distress via an asset sale. ${ }^{14}$ In our regressions explaining firm recovery rates we find a positive effect of asset structure, bank debt, continuation in bankruptcy and a negative effect for leverage and piecemeal liquidation. The positive effect of bank debt points at an incentive effect for banks, which are willing to employ more effort in case relative bank debt is higher. The fact that continuation in bankruptcy generates a higher recovery is also important. Even in the Dutch liquidation-based system, $46.7 \%$ of the firms are continued in bankruptcy. Bank debt recovery rates are on average $80 \%$ in our sample. This is comparable to what is found in other studies (see Franks and Torous 1994; Thorburn 2000; Bris et al. 2006). The regression analyses on bank debt recovery rates yield a negative effect of firm size, leverage and liquidation, while positive effects come from the collateral securing bank debts and the variable debtor filing. Overall, our findings again indicate that firm characteristics are more important determinants of recovery rates than the legal procedures in the bankruptcy process.

Our results on direct costs and recovery rates both indicate that the Dutch legal rules do not frustrate recovery nor raise costs. This setting leads to the situation in which firm-specific variables drive the efficiency in bankruptcy resolution. These conclusions are consistent with the findings of Djankov et al. (2006) on the efficiency of the Dutch legal regime. Our findings falsify the idea that liquidationbased regimes are bound to lead to inefficient over-liquidation. Direct costs and recovery rates are in line with other studies on firms in liquidation-based as well as reorganization-based systems. Furthermore, financial distress is in many cases quickly resolved via a going concern asset sale, while in many other cases the possibility for continuation in bankruptcy mitigates value losses.

Acknowledgements We express thanks to Anton Duizendstraal, Daniël Hoekstra, Tao Jiang, Thuy Nguyen, Peter Roosenboom, Sonja Tomas and an anonymous referee for comments. The authors thank Marjolein van den Boogert, Anton Duizendstraal, Reinier Koopman, Sander Timmerman and Vincent Vogel for their research assistance. The major part of this research has been conducted when Couwenberg was a researcher to the Business and Law Research Centre of the Radboud University Nijmegen. Part of this research has been made possible by a grant of the Dutch Ministry of Economic Affairs.

Open Access This article is distributed under the terms of the Creative Commons Attribution Noncommercial License which permits any noncommercial use, distribution, and reproduction in any medium, provided the original author(s) and source are credited.

\section{References}

Armour, J., Hsu, A., \& Walters, A. (2006). The costs and benefits of secured creditor control in bankruptcy: Evidence from the UK. Working Paper Centre for Business Research, University of Cambridge, No. 332.

Baird, D. (1996). A world without bankruptcy. In J. S. Bhandari \& L. A. Weiss (Eds.), Corporate bankruptcy, economic and legal perspectives (pp. 29-38). New York: Cambridge University Press.

\footnotetext{
${ }^{14}$ As such this argument can be seen as a corollary to the idea proposed by Haugen and Senbet (1978) that bankruptcy costs are capped to the costs it takes to buy the financial claims on the capital market. Only here it is the asset market that takes over that function.
} 
Baird, D., Bris, A., \& Zhu, N. (2005). The dynamics of large and small chapter 11 cases: An empirical study. Yale ICF Working Paper No. 05-29.

Betker, B. L. (1995). An empirical examination of prepackaged bankruptcy. Financial Management, 24, 3-18. doi:10.2307/3665873.

Betker, B. L. (1997). The administrative costs of bankruptcy: Some recent evidence. Financial Management, 26, 56-68. doi:10.2307/3666127.

Bris, A., Welch, I., \& Zhu, N. (2006). The costs of bankruptcy: Chapter 7 liquidation versus chapter 11 reorganization. Journal of Finance, 59, 1253-1303. doi:10.1111/j.1540-6261.2006.00872.x.

Brown, D. T. (1989). Claimholder incentive conflicts in reorganization: The role of bankruptcy law. Review of Financial Studies, 2, 109-123. doi:10.1093/rfs/2.1.109.

Calabresi, G. (1970). The costs of accidents. New Haven: Yale University Press.

Citron, D., Wright, M., Ball, R., \& Rippington, F. (2003). Secured creditor recovery from management buy-outs in distress. European Financial Management, 9, 141-161. doi:10.1111/1468-036X.00213.

Claessens, S., \& Klapper, L. F. (2005). Bankruptcy around the world: Explanations and relative use. American Law and Economics Review, 7, 253-283. doi:10.1093/aler/ahi004.

Couwenberg, O. (2001). Survival rates in bankruptcy systems: Overlooking the evidence. European Journal of Law and Economics, 12, 253-273. doi:10.1023/A:1012821909622.

Davydenko, S. A., \& Franks, J. R. (2005). Do bankruptcy codes matter? A study of defaults in France, Germany and the UK. Working Paper London Business School.

Djankov, S., Hart, O., McLiesh, C., \& Shleifer, A. (2006). Debt enforcement around the world. NBER Working Paper Series, nr. 12807.

Ferris, S. P., \& Lawless, R. M. (2000). The expenses of financial distress: The direct costs of chapter 11. University of Pittsburgh Law Review, 61, 629-669.

Franks, J. R., \& Sussman, O. (2005). Financial distress and bank restructuring of small to medium sized UK companies. Review of Finance, 9, 65-96. doi:10.1007/s10679-005-2988-8.

Franks, J. R., \& Torous, W. N. (1994). A comparison of financial recontracting in distressed exchanges and chapter 11 reorganizations. Journal of Financial Economics, 35, 349-370. doi: 10.1016/0304-405X(94)90037-X.

Franks, J. R., Nyborg, K. G., \& Torous, W. N. (1996). A comparison of US, UK, and German insolvency codes. Financial Management, 25, 86-101. doi:10.2307/3665810.

Gertner, R., \& Scharfstein, D. (1991). A theory of workouts and the effects of reorganization law. Journal of Finance, 46, 1189-1222. doi:10.2307/2328856.

Gilson, S. C. (1997). Transactions costs and capital structure choice: Evidence from financially distressed firms. Journal of Finance, 52, 161-195. doi:10.2307/2329560.

Gilson, S. C., John, K., \& Lang, L. H. P. (1990). Troubled debt restructurings: An empirical study of private reorganization of firms in default. Journal of Financial Economics, 27, 315-353. doi: 10.1016/0304-405X(90)90059-9.

Haugen, R. A., \& Senbet, L. W. (1978). The insignificance of bankruptcy costs to the theory of optimal capital structure. Journal of Finance, 33, 383-393. doi:10.2307/2326557.

Holmstrom, B., \& Myerson, R. B. (1983). Efficient and durable decision rules with incomplete information. Econometrica, 51, 1799-1819. doi:10.2307/1912117.

Hotchkiss, E. S. (1995). Postbankruptcy performance and management turnover. Journal of Finance, 50, 3-21. doi:10.2307/2329237.

Jensen-Conklin, S. (1992). Do confirmed chapter 11 plans consummate? The results of a study and analysis of the law. Commercial Law Journal, 97, 297-331.

La Porta, R., Lopez-de-Silanes, F., \& Shleifer, A. (1998). Law and finance. Journal of Political Economy, 106, 1113-1155. doi:10.1086/250042.

Lopucki, L. M., \& Doherty, J. W. (2004). The determinants of professional fees in large bankruptcy reorganization cases. Journal of Empirical Legal Studies, 1, 111-141. doi:10.1111/j.17401461.2004.00004.x.

Lubben, S. J. (2000). The direct costs of corporate reorganization: An empirical examination of professional fees in large chapter 11 cases. American Bankruptcy Journal, 74, 509-551.

Maksimovic, V., \& Phillips, G. (1998). Asset efficiency and reallocation decisions of bankrupt firms. Journal of Finance, 53, 1495-1532. doi:10.1111/0022-1082.00063.

Ravid, S. A., \& Sundgren, S. (1998). The comparative efficiency of small-firm bankruptcies: A study of the US and the Finnish bankruptcy codes. Financial Management, 27, 28-40. doi:10.2307/3666411. 
Sundgren, S. (1998). Does a reorganization law improve the efficiency of the insolvency law? The Finnish experience. European Journal of Law and Economics, 6, 177-198. doi:10.1023/A: 1008045330708

Tashijan, E., Lease, R. C., \& McConnell, J. J. (1996). Prepacks, an empirical analysis of prepackaged bankruptcies. Journal of Financial Economics, 40, 135-162. doi:10.1016/0304-405X(95)00837-5.

Thorburn, K. S. (2000). Bankruptcy auctions: Costs, debt recovery, and firm survival. Journal of Financial Economics, 58, 337-368. doi:10.1016/S0304-405X(00)00075-1.

Weiss, L. A. (1990). Bankruptcy resolution, direct costs and violation of priority of claims. Journal of Financial Economics, 27, 285-314. doi:10.1016/0304-405X(90)90058-8.

White, J. M. (1996). The costs of corporate bankruptcy: A U.S.-European comparison. In J. S. Bhandari \& L. A. Weiss (Eds.), Corporate bankruptcy, economic and legal perspectives (pp. 467-500). New York: Cambridge University Press. 